\title{
Development of Methodology for Assessing Human Capital Productivity
}

\author{
Akhmetshina Alsu Rinatovna', Gabdullin Nail Maratovich', Kirshin IgorAlexandrovich ${ }^{3}$ \\ ${ }^{1}$ Kazan Federal University, Dean of Higher School of Business, Doctor of Economics, Russia \\ ${ }^{2}$ Kazan Federal University, Associate Professor, Institute of Management, Economics and Finance, Russia \\ ${ }^{3}$ Kazan Federal University, Professor of Higher School of Business, Doctor of Economics, Russia
}

\begin{abstract}
.
The article proposes a methodological approach and develops a methodology for assessing the productivity of human capital. The author's methodology for measuring the productivity of human capital was developed, based on the use of the Jorgenson-Fraumeni methodological approach and a multivariate model for assessing productivity, including the measurement of the potential and factors of non-economic development of human capital The authors established a close statistically significant correlation of per capita national wealth and stocks of per capita human capital, per capita human capital and Gross Domestic Product per worker, as well as per capita human capital and per capita Gross Domestic Product. Based on evidence of the dominance of the human capital input to gross output, a hypothesis has been put forward and substantiated according to which human capital has higher productivity compared to other factors of production. Based on an empirical analysis of the World Bank dataset for 142 countries, the article proves the inverse relationship of human capital productivity, measured as the quotient of dividing per capita Gross Domestic Product by per capita human capital. The maximum return on Gross Domestic Product per capita is shown by the Senegal economy, as the economy with the smallest stock of human capital, the minimum - the economy of Iceland, the leader in terms of human capital stocks.
\end{abstract}

Keywords: intangible assets; labor productivity; national wealth; total factor productivity; skills 


\section{Introduction}

One of the methodological principles of human capital management is its measurability. While a lot of writings deal with the theory and methodology of measuring human capital, methods for assessing the productivity of human capital (Human Capital Productivity, HCP) are not sufficiently developed due to their specificity. Historically, A. Smith considered the productive abilities of the individual as elements of capital [Smith, 1962]. Contemporary researchers also define human capital as "a stock of economically productive human opportunities"[Behrman, 1982]. P. Romer considered human capital as the major source of economic productivity. He argued that in creating economic goods, only knowledge and human capital are used [Romer, 1990]

This position is shared by other researchers, who argue that, in the knowledge economy, competitive advantages are provided mainly by the growth of the productivity of mental and intellectual labor [Drucker, 2009]. The American economist L. C. Thurow, based upon the results of generalization of studies of human capital, defined the latter as the ability to produce economic benefits. In his opinion, a person's economic ability can be interpreted as an individual's productive investment that affects the productivity of all other investments [Thurow, 1970].

\section{Methods}

The development of a methodology for studying the productivity of human capital is possible through the application of B. Fraumeni's methodological approach[Fraumeni, 2012]. Despite the repeatedly noted shortcomings of human capital assessment method by investment in education, the average duration of education remains one of the main indicators identifying the stock of human capital[Schultz, 1961]. Keeping in mind that this indicator does not fully determine the investment of education to the accumulation of human capital, T. Schultz and G. Becker defined education as a more general concept of investment in human capital [Becker, 1987]. T. Schulz conducted a comprehensive analysis of the relationship between investment in human capital and individual income[Schultz, 1988]. An empirical analysis of cross-country data has shown that with increasing levels of education, labor productivity and national income per capita increase[Barro \&Lee, 2000]. However, when simulating the dynamics of economic growth using the duration of studies factor, researchers found differences in output in different national economies[Casseli, 2003]. They were able to account for this phenomenon by the disparity of each year of study in different countries.

The researchers came to the conclusion that for a more accurate assessment of human capital, it is necessary to take into account the quality of education, as measured, for example, by the regularity of updating educational programs, the qualifications of teaching staff, the availability of teaching materials, the ratio of students and teachers, the results of independent testing of students, etc. For this reason, indicators of the average duration of education are supplemented by structural indicators that reflect the proportion of the population who have received a certain level of education (for example, primary, secondary and higher). 
Another important factor that builds national wealth is the quality of national institutions that adequately reflects the effectiveness of public administration and the state of the country's social capital. In simulation, researchers take these factors into account by including into the variable the intangible capital of "the institutional infrastructure of the country and its organization; social capital, that is, the level of trust among people and their ability to work together to achieve common goals."[Silvestrov\&Parfiryev, 2008].

M. Paldam and G. Svendsen linked social capital to the level of public trust and presented an overall index of trust for 20 countries[Paldam, 2005]. In addition, net financial assets are included in intangible capital, which, due to the lack of comprehensive intercountry data on net foreign financial assets, cannot be taken into account in assessments of total national welfare.

A significant contribution to the development of this line in the 1960s was made by the American economist E. Denison[Denison, 1985; Russia and competitors]. He developed proposals for a range of measures conducive to economic growth: an increase in working hours and accumulation rates, an influx of skilled migrants, an increase in the educational level and advanced training of workers, an improvement in the organization of production and management, a more efficient use of resources, and an increase in the concentration level of production (economies of scale), increased research expenses. These factors were used by IBRD specialists to assess the input of intangible capital to labor productivity growth. Thus, E. Denison determined the interdependence of the growth of productivity of human capital and the use of intensive factors of economic growth. In his further studies, A factorial assessment of gross output growth occurs through its decomposition into the following components: the input of the quantity of living labor, the input of the quality of living labor, the input of information capital, the input of other tangible capital and the input of TFP growth.

In accordance with R. Solow's residual method, decomposition method and TFP estimation methods, the contribution of human capital determinants to output growth can be estimated using the following algorithm:

Iteration 1.

Estimation of total intangible capital:

- calculation of the natural logarithm of intangible capital as the difference between the natural logarithm of gross output and the sum of the logarithms of capital and labor, taking into account the corresponding elasticities;

- $\quad$ calculation of total intangible capital:

$$
I=e^{\ln Y-\alpha \ln K-(1-\alpha) L-\varepsilon}
$$

Iteration 2.

Subtraction from intangible capital of net financial assets.

Iteration 3. 
Building a dynamic model of the regression dependence of $I(t)$ on exogenous variables that make up intangible capital. To build a dynamic model, we introduce the factor of accumulation of intangible capital into the Cobb-Douglas production function by the formula of continuous compounding with an annual rate of $r$ :

$$
Y=K^{\alpha} L^{1-\alpha} e^{r t}
$$

where

$\mathrm{e}^{\mathrm{rt}}$ - is the factor of accumulation of intangible capital with a rate of $r$. The Cobb-Douglas static production function is converted into a dynamic production function. The main result of the accumulation of intangible capital is an increase in the efficiency of the production process, accompanied by an increase in the return on labor and capital. Differentiation of the logarithm of this function by time factor yields the following result:

$$
G Y=\alpha G_{K}+(1-\alpha) G_{L}+r
$$

where $G_{Y}$ - is the average annual growth rate of output, $G_{L}$ - is the average annual growth rate of labor, $\mathrm{G}_{\mathrm{K}}$ is the average annual growth rate of capital, $\mathrm{r}$ is the average annual growth rate of intangible capital.

The input of intangible capital (in \%) to output growth is estimated as

$$
\frac{r}{G Y} \approx 1-\left[\frac{\alpha \ln K}{\ln Y}+\frac{(\alpha-1) \ln L}{\ln Y}\right]
$$

The initial statistical data of the model can be generated from annual (quarterly) observations of macroeconomic indicators of the national economy. To measure physical capital, a continuous inventory method can be used. The capital stock in this method is determined by cumulative investment flows, and the capital outflow is calculated using the depreciation function[Solow, 1957]. The change in capital stock is described by the following equation:

$$
\frac{d K}{d t}=s Y-\delta K
$$

Net capital stock is calculated by the formula:

$$
K_{t}=K_{t-1}(1-\delta)+I n v t
$$

where, $K_{t}$ is the stock of capital at constant prices in the period $\mathrm{t}$,

$\delta$ is the depreciation rate,

$\mathrm{Inv}_{\mathrm{t}}$ - investments in year $\mathrm{t}$ (gross fixed capital formation at constant prices).

The model we developed represents intangible capital as a function of the explanatory variables of human capital and social capital. Human capital includes education capital and 
health capital. Education capital can be measured by proxies of variable average duration of employee training. To assess health capital, we shall apply the methodology for determining the World Bank Human Capital Index using two proxy indicators of general health status used in the human capital index:

- an indicator of the prevalence of short stature among children under the age of 5 years,

- an indicator of adult survival[Kraay, 2018].

The measure of social capital can be expressed by the rule of law index[WJP Rule]. Then the model for assessing intangible capital shall be described by the following equation:

$$
I=A S^{\alpha S} H^{\alpha H}{ }^{\alpha L}
$$

where I is intangible capital, $\mathrm{A}$ is a constant, $\mathrm{S}$ is the mean years of schooling for a population, $\mathrm{H}$ is an integrated index of health capital, and $\mathrm{L}$ is the rule of law index. Coefficients $\mathrm{aS}, \mathrm{aH}$ and aL express the elasticity of intangible capital with respect to explanatory variables. So, for example, aS measures the growth rate I with an increase in the years of schooling by one.

Using the elasticity coefficients obtained in the regression model, it is possible to calculate the marginal yield of the input of each explanatory variable, showing how much I will change when the explanatory variable changes by one, while the other explanatory variables are constant. Marginal yield values are calculated through partial derivative functions. For example, for fixed values of $\mathrm{H}$ and $\mathrm{L}$, the partial derivative with respect to the formation variable:

$$
\frac{\partial I}{\partial S}=A \alpha S S^{\alpha S-1} H^{\alpha H} L^{\alpha L}
$$

is equal to the marginal productivity of the education factor.

$$
\frac{\partial I}{\partial S}=\alpha S \frac{I}{S}
$$

Assuming constant elasticity, marginal yield shall depend on level I and S.

Using the Cobb-Douglas production function method allows us to write the following equation[Where is the Wealth, 2006]:

$$
I=\frac{\partial I}{\partial S} S+\frac{\partial I}{\partial H} H+\frac{\partial I}{\partial L} L+Z
$$

Thus, intangible capital is decomposed into the components of education, health and management. Component $\mathrm{Z}$ reflects the difference between intangible capital and the individual inputs of the explanatory variables. If the sum of the elasticity coefficients aS, aH, and aL is equal to one, then $\mathrm{Z}$ is zero. Assuming that $\mathrm{Z}$ is zero, we can estimate the input of human capital and social capital to intangible capital and, further, to the growth of labor productivity. 


\section{Results and Discussion}

When developing analytical tools for assessing the productivity of human capital, it is necessary to proceed from well-known stylized facts, in particular, from the final transition from labor-intensive to capital-intensive production technologies in the 20th century. It was machines and equipment that supplanted the labor of people that began to determine the scale and dynamics of production. The fourth industrial revolution significantly increased the importance of the technological component and TFP, which directly depend on the level of productivity of human capital.

Let us consider the well-known method of assessing labor productivity, which consists in correlating the value of the product of labor and labor costs for its production. Methodologically, the assessment of labor productivity is carried out through the calculation of production (Revenue Per Employee, RPE) using the natural (semi-natural) method and the cost method. Production is defined as the volume of production per employee (table 1) or as the ratio of the cost of production produced per unit of time (hour, day, year). "The total amount of time worked on all types of work (total labor costs) for the production of goods and services is calculated by multiplying the number of jobs for each type of work by the average actual hours worked per job."[Labor productivity, 2017].

Table 1: The Top 10 Tech Companies by Revenue Per Employee

\begin{tabular}{|c|c|c|}
\hline Rank & Company & Revenue per employee \\
$\# 1$ & Apple & $\$ 1,859,000$ \\
\hline$\# 2$ & Facebook & $\$ 1,621,000$ \\
\hline$\# 3$ & Alphabet & $\$ 1,253,000$ \\
\hline$\# 4$ & VeriSign & $\$ 1,154,000$ \\
\hline$\# 5$ & Visa & $\$ 1,062,000$ \\
\hline$\# 6$ & Mastercard & $\$ 906,000$ \\
\hline$\# 7$ & Broadcom & $\$ 843,000$ \\
\hline
\end{tabular}

Source: [Desjardins, 2017]

RPE depends on labor intensity. In labor-intensive industries, RPE is lower, in hi-tech it is higher, since the labor intensity of products is lower there. The data show that, on average, the output per employee in companies in the energy sector is at least 2 times higher than in other sectors.

It is known that labor productivity in High-income countries is higher than in Lowincome countries. However, this does not mean a greater return on human capital in Highincome countries than in Low-income countries. To prove this hypothesis, we shall conduct an 


\section{$4^{\text {th }}$ International Conference on BUSINESS, MANAGEMENT \& ECONOMICS}

empirical analysis of World Bank data for a sample of 142 countries. First, we note that the proportion of human capital in the national wealth of all national economies prevails (table 2).

Table 2: Wealth, by Type of Asset and Region, 2014

\begin{tabular}{|l|c|c|c|c|c|c|}
\hline & $\begin{array}{c}\text { Low- } \\
\text { income } \\
\text { countries } \\
(\%)\end{array}$ & $\begin{array}{c}\text { Lower- } \\
\text { middle- } \\
\text { income } \\
\text { countries } \\
(\%)\end{array}$ & $\begin{array}{c}\text { Upper- } \\
\text { middle- } \\
\text { income } \\
\text { countries } \\
(\%)\end{array}$ & $\begin{array}{c}\text { High- } \\
\text { income } \\
\text { countries } \\
(\%)\end{array}$ & $\begin{array}{c}\text { High- } \\
\text { income } \\
\text { Non- } \\
\text { OECD } \\
\text { countries } \\
(\%)\end{array}$ & $\begin{array}{c}\text { High- } \\
\text { income } \\
\text { OECD } \\
\text { countries } \\
(\%)\end{array}$ \\
\hline $\begin{array}{l}\text { Produced } \\
\text { capital }\end{array}$ & 14 & 25 & 25 & 22 & 28 & 27 \\
\hline $\begin{array}{l}\text { Natural } \\
\text { capital }\end{array}$ & 47 & 27 & 17 & 30 & 3 & 9 \\
\hline $\begin{array}{l}\text { Human } \\
\text { capital }\end{array}$ & 41 & 51 & 58 & 42 & 70 & 64 \\
\hline $\begin{array}{l}\text { Net foreign } \\
\text { assets }\end{array}$ & -2 & -3 & 0 & 5 & -1 & 0 \\
\hline
\end{tabular}

Source: Drawn up by authors based on [Lange et al., 2018]

Secondly, per capita human capital is closely correlated with GDP per capita (Fig. 1). The Pearson correlation coefficient of per capita human capital and per capita GDP is 0.875982186 , and the correlation coefficient is also statistically significant.

Consequently, human capital makes the largest input to gross output. This determines its greater productivity in comparison with other factors of production. 


\section{$4^{\text {th }}$ International Conference on BUSINESS, MANAGEMENT \& ECONOMICS}

15 - 17 DECEMBER 2020

BERLIN, GERMANY

Figure 1: Human capital per capita and GDP per capita

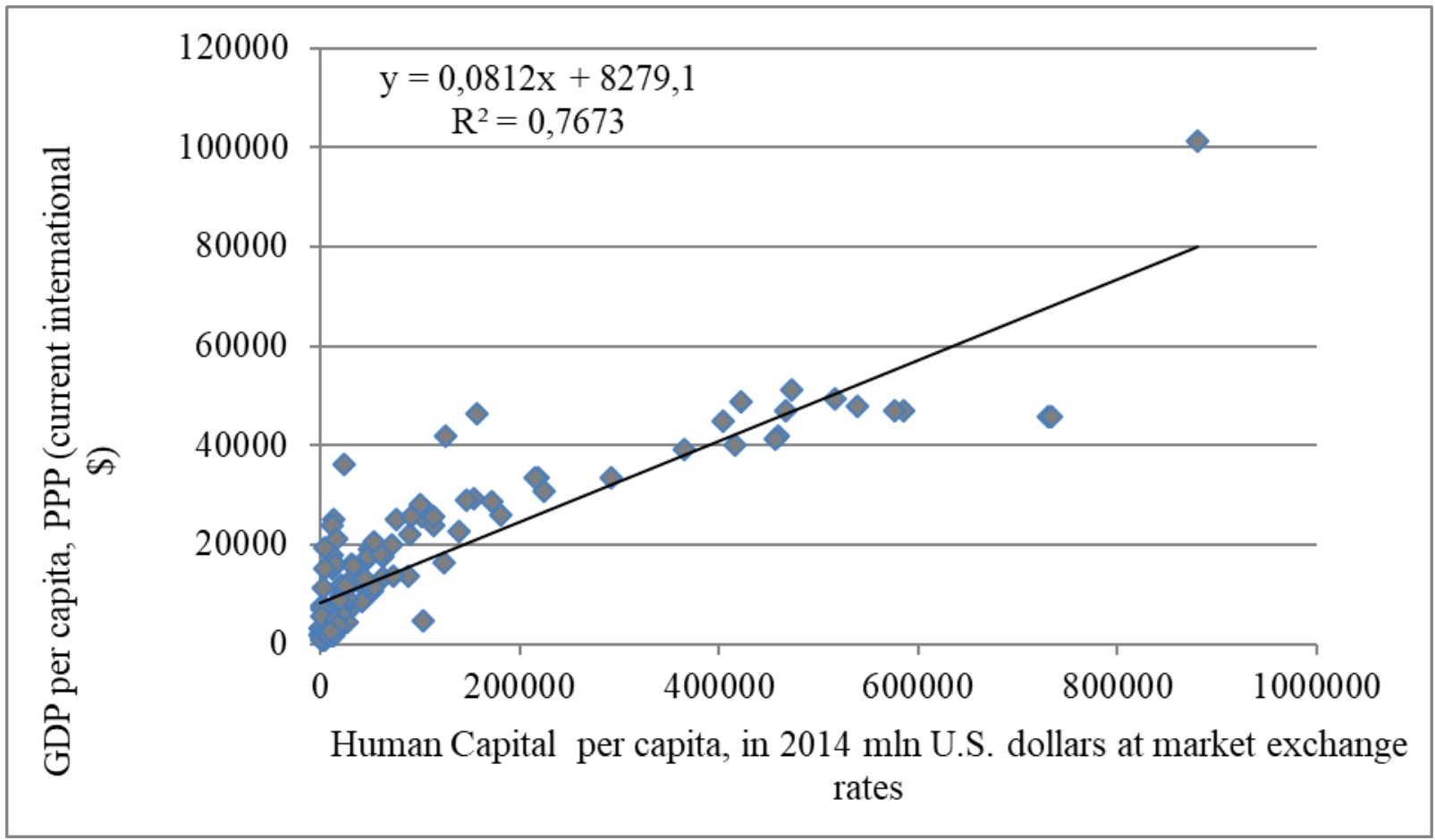

Source: Drawn up by authors based on [22]

Lastly, based on our findings, let us establish the nature of the dependence of the productivity of human capital and its stock. To do this, we calculate the return on human capital as the quotient of dividing per capita GDP by capita human capital (Fig. 2).

Figure 2: Return on human capital by GDP per capita, PPP (current international \$)

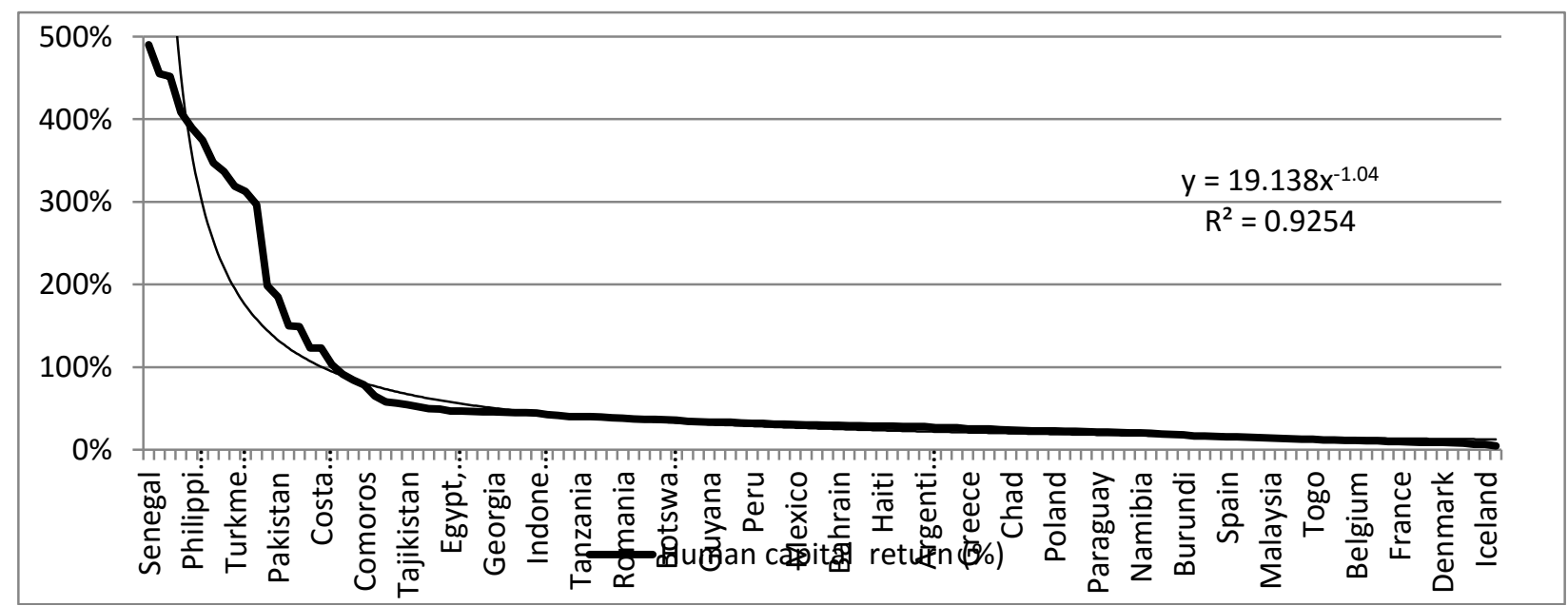

Source: Drawn up by authors based on [22] 
In this case a pronounced inverse relationship is recorded. Thus, the highest return on GDP per employee is shown by the economy of Senegal at $1442.81 \%$, and the lowest - by the economy of Iceland at $9.81 \%$. According to per capita GDP, the economy of Senegal is also leading $-489.94 \%$, the economy of Iceland concludes the rating with a return on human capital of $6.23 \%$.

\section{Conclusion}

As noted above, assessments of the cost of human capital in different countries are not comparable for reasons of incomplete availability of data on wages and incompatibility of data on education. The difficulty of comparing the assessments obtained and the source data in different countries is due to differences in definitions, assessment methods and assumptions. There are limitations in assessments of human capital due to the number of comparable observations. The model we proposed based on the measurement of national wealth provides opportunities for advancement in methods for assessing the productivity of human capital.

The developed methodology for assessing the productivity of human capital allows getting answers to many questions of human capital management and, in particular, to establish ways to influence the productivity of human capital. In the knowledge economy, competitive advantages are provided mainly by the growth of the productivity of mental, intellectual labor[4]. Managing the productivity of human capital decides the efficiency of production of economic goods. A person's productive abilities can be interpreted as an individual's productive investment that affects the productivity of all other investments. The concept of managing human capital productivity technically provides assessment of the input of human capital to the dynamics of economic growth.

\section{Acknowledgements}

The work is performed according to the Russian Government Program of Competitive Growth of Kazan Federal University. 


\section{References}

Smith, A. (1962). An Inquiry into the Nature and Causes of the Wealth of Nations. - Moscow: Sotsegiz, . - P. 492[in Russian].

Behrman, J.R., Taubman. P. J. (1982). Human Capital. In Encyclopedia of Economics, , ed. Douglas Greenwald, New York: McGraw-Hill Book Company. - P.474-476.

Romer, P. (1990).Endogenous Technological Change Journal of Political Economy, Vol. 98(5). PP. 71-102.

Drucker, P.F. (2009). Innovation and Entrepreneurship.[Translation from English]. - Moscow: OOO I. D. Williams, - P. 432 [in Russian].

Thurow, L. (1970). Investment in Human Capital. Belmont. 104 p.

Fraumeni, B.M. (2012). Human Capital Productivity: A New Concept for Productivity Analysis, International Productivity Monitor. № 24, Fall

Schultz, T. W. (1961). Investment in Human Capital. American Economic Review, 51, PP.1-17.

Becker, G.S. (1987). Economic Analysis and Human Behavior, In: L.Green and J.Kagel (eds.) Advances in Behavioral Sciences. Norwood (N.J.): Ablex Publ. Corp., V.1, PP. 3-17.

Schultz, T. W. (1988). Education Investments and Returns In Handbook of Development Economics, Volume 1, ed. H. Chenery and T. N. Srinivasan. Amsterdam: Elsevier Science Publishers, B.V.

Barro, R., and Lee, J. W. (2000). International Data on Educational Attainment: Updates and Implications. CID Working Paper 42, Center for International Development, Harvard University, Cambridge MA. NIER (National Institute for Economic Research). Environmental Impacts of Swedish Trade-Results of a pilot study. Stockholm. Data on school years are from Barro and Lee 2000 .

Caselli, F (2003) Forthcoming. "The Missing Input: Accounting for Cross-Country Income Differences." In Handbook of Economic Growth, ed. P. Aghion and S. Durlauf. Amsterdam: NorthHolland.

Silvestrov, S.N., Porfiryev, B.N. (2008) National wealth: evaluation and management of economic growth Edited by S.M. Shahray and E.I. Ivanova Moscow Ekonomicheskiye Nauki [in Russian].

Paldam, M. (2005) Social Capital Database for a Cross-Country Study / M. Paldam, G.T. Svendsen // Trust, Social Capital and Economic Growth: An International Comparison / M. Paldam, G.T. Svendsen (eds.).- Cheltenham, UK: Edward Elgar Publishing

Denison, E (1985) Trends in American Economic Growth, 1929-1982 Washington, D. C.: The Brookings Institution

Russia and competitors - who wins the productivity race? [Online]. Available: https://www.finam.ru/analysis/forecasts/rossiya-i-konkurenty-kto-pobedit-v-gonke-zaproizvoditelnostyu-20190514-16168/[in Russian]. 


\section{$4^{\text {th }}$ International Conference on BUSINESS, MANAGEMENT \& ECONOMICS}

Solow, R. (1957). Technical change and the aggregate production function Review of Economics and Statistics. № 39. PP. 312-320.

Kraay, A (2018). Methodology for a World Bank Human Capital Index. Policy Research Working Paper 8593, World Bank, Washington, DC.

WJP Rule of Law Index® 2018-2019.[Online]. Available: http://data.worldjusticeproject.org/

Where is the Wealth of Nations? Washington, D.C.: World Bank, 2006. - P. 96.

Labor productivity in the Russian Federation. Social Bulletin, June 2017. [Online]. Available: https://ac.gov.ru/files/publication/a/13612.pdf [in Russian].

Desjardins, J. (2017). The Top 20 Tech Companies by Revenue Per Employee Published 2 years go on August 23, [Online]. Available: URL: https://www.visualcapitalist.com/top-20-techcompanies-revenue-per-employee//.

Lange, G.-M., Wodon, Q, and Carey, K (2018). The changing wealth of nations. Building a Sustainable Future. 2018 International Bank for Reconstruction and Development. - P. 8., The World Bank. [Online]. Available: https://openknowledge.worldbank.org/handle/10986/29001. 